The means of thirty-eight stations since 1876 give similar results, viz. :-

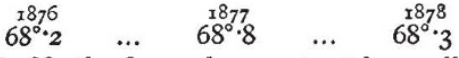

For 1879 and 1880 the figures have not yet been all worked up, but as far as they have been reduced they indicate that the intensity of solar radiation was a good deal less than in $\mathbf{1} 878$.

Allahabad, February 3

S. A. Hill

\section{The Continents always Continents}

Mr. WALLACE, in his recent excellent work on "Island Life," places me in a wrong relation to the question as to the continents having always been continents, After sustaining the view at length in Chapter VI. of his work, without any reference to my arguments on the subject, he later, in Chapter IX., says that "it appears to be the general opinion of geologists [ sic $]$ that the great continents have undergone a process of development from earlier to later time:," and then quotes a paragraph of mine by way of proof.

My first discussion of the subject was published in the American Fournal of Science for 1846 (vol. ii. of second ser. p. 352), where the "opinion" is partly speculative, the origin of the continents being made one of the initial results of the earth's refrigeration but it is not left without the mention of facts sustaining it derived from the actual geological progress of the American continent. In the following volume, in an article entitled "On the Origin of Continents," the view is presented at more length, with some additional confirmatory facts connected with the structure of the continent; and facts from the exrth at larye bearing the same way are brought out in a second paper, "On the Origin of the Grand Outline Features of the Earth." In my "Geological Report" (published in r849) of the Wilkes Exploring Expedition around the World, in which the same views are briefly presented (p. 431), I argue against "the existence of a continent in the Pacific Ocean within any of the more recent geological epochs" [referring here to those of the Tertiary and Quaternary], on the ground of "the absence of all native quadrupeds from its islands, and even from New Zealand."

A few years later (in 1856) I published, in vol. xxii. of the American Fournal, two papers under the titles "On American Geological History" and "On the Plan of Development in the Geological History of North America," and in them I gave what I have regarded as a geological demonstration of the view by stating with some detail the facts with respect to the succes. sively-developed features and geological formations of the American continent. Again, in my "Manual of Geology," the first edition (that of 1863 ), the progress of the rocks and mountains of the continent is traced out, from the V-shaped Archæan (Azoic) nucleus, in British America, onward; and in the account of the Archæan the statement is made (p. 136) that the structure lines apparent over the continent at the close of Archæan time were "features that were never afterwards effaced; instead of this, they were manifested in every new step in the progress of the continent"; and in the edition of the Manual of 1874 , after a fuller account of the positions of Archæan mountains, it is then added (p. 160): "Hence, in the very inception of the continent, not only was its general topography foreshadowed, but its main mountain chains appear to have been begun, and its great intermediale basins to have been defined-the basin of New England and New Brunswick on the east; that between the Appalachians and the Rocky Mountains over the great continental interior that of Hudson's Bay, between the arms of the northern V. The evolution of the grand structure-lines of the continent was hence early commenced, and the system thus initiated was the system to the end. Here is one strong reason for concluding that the continents have always been continents; that, while portions may have at times been submerged some thousands of feet, the continents have never changed places with the oceans. Tracing out the development of the American continent from these Archæan beginnings is one of the main purposes of geological history." In the course of the following pages (nearly 400 ) on Historical Geology in both editions, the evidence on this point is variously set forth-evidence afforded by the limits of the successive geological formations, by the occurrence of beds of shallow-water deposition at many levels in the long series, and by the progressive origin of the mountain-ranges. Then, in the edition of 1874 (and also that of 1880 ) I bring in (p. 525) the paragraph which Mr. Wallace cites in his Chapter IX. (p. 196)-not as the expression of an "opinion," but as the summing up after a demonstration.
The view that the continents have always been continents, which I have held for forty years, is written so plainly in the geology of North America that $I$ am sure it would never have been set down among speculations, even by the most exacting of British geologists, had attention been fairly given to American facts. If the truth is not taught by British rocks, it is because these represent only a narrow margin of a continent, and hence could not be expected to illustrate general continental develop. ment, hardly more than an animal's leg, however profoundly studied, the embryological laws of the species.

New Haven, Connecticut, February 8

James D. Dana

\section{The Aurora of January $3 \mathrm{I}$; Position of Auroral Rays}

THE bright loop shown in G. F. Seabroke's drawings of the aurora on January $3 \mathrm{I}$ at 6.30 and 6.35 p.m., as seen at Rugby, remind me of a striking feature seen here. If it was the same, a comparison of the observations will give some idea of the

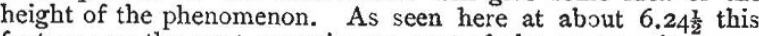
feature was the most conspicuous part of the aurora; it was a somewhat pear-shaped bright patch, with a region along the middle of it not quite so bright. Its edge was $10^{\circ}$ above the moon, at Venus, Jupiter, $\beta$ and $\eta$ Pegasi ; its pointed end being low down, and a good deal further to the right. At $6.26 \frac{1}{2}$ Venus was in the midst of its left end, and Jupiter quite outside. The moon was $5^{\circ}$ below the lower edge. The clusky region gradually darkened, and finally opened through the right end of the patch, which became united by a rather serpentine bright band to a somewhat similar, but partly red, bright patch rising up in the east-north-east. This bright band formed the southern border of the aurora. At $6.31 \frac{1}{2}$ the position of the central line of this band, including the western bright patch which now formed a loop in it open to the north, was about as follows:-At or near the moon, one-third of the way from ‘ Ceti to Venus, $\zeta$ Cygni (the junction of the patch with the new band), a Pegasi I think, $\beta$ Trianguli, $\alpha$ Tauri, and below Procyon.

The motion of these features, as well as of all the large masses of the aurora throughout the evening, was approximotely from east to west (magnetic), so far as I could observe. The four or more arches seen at Rugby by G. M. Seabroke at 6.35 were not seen by me.

The spectrum of this aurura was very similar to those of February 4, 1874, and October 4, 1874, as given in Capron's "Auroræ," Plate V.; the band marked 4 of the former being sometimes present and sometimes absent. I also saw traces of the red line at times.

I am surprised that Prof. S. P. Thompson (NATURE, vol. xxiii. p. 289) is not aware that it is a thoroughly ascertained fact that the rays of auroras lie in the direction of the magnetic dip. I may add that the flashes or pulsations also generally appear to move away from the earth in the direction of the magnetic dip.

Sunderland, February 24

T. W. BACKHOUSE

\section{Auroric Light}

As Mr. W. H. Preece records the magnetic storms, if not too much trouble would he record what took place on the night of January 16 ? - as at midnight there was all the appearance of a grand display; but as the windows were all frost-masked, and my only place of observation was exposed to a cutting wind that would have "shaved a cast-iron policeman," to quote Punch, I could not observe what took place. I should also like to know why the grand displays this winter are of white lights. Those I saw in previous years - the best being while stationed in West Galway between 1867 to 1872 -were principally red lights, some of them being most brilliant between midnight and morning, while all of them this year have been best early in the night, all lights usually disappearing before or a little after eleven. I am used to white lights in the summer months, but I never before saw them so prominent in the winter months-main lights, cross lights, and glows being white; while usually, each respectively have different colours. I have not seen an aurora that changes so much in character as the last, except that of September, 1867 or I868 (I think, but I have not my notes to give the exact year). That of 1867 or 1868 was a grand display, rising in a red mass to the zenith, and then shooting out pencils of red, green, white, purple, and orange lights.

Ovoca, February 20 